\title{
PENGARUH PEMBERIAN PENGUATAN OLEH GURU TERHADAP HASIL BELAJAR SISWA DALAM PEMBELAJARAN PENDIDIKAN KEWARGANEGARAAN
}

\author{
Rohani ${ }^{1}$, Maman ${ }^{2}$, Sulha ${ }^{3}$ \\ 1, 2, 3 Program Studi PPKn Fakultas Ilmu Pendidikan dan Pengetahuan Sosial IKIP PGRI Pontianak \\ Jl. Ampera Nomor 88 Pontianak-78116, Telepon (0561) 748219 Fax. (0561) 6589855 \\ email: ${ }^{1}$ rohani@ikippgriptk.ac.id
}

\begin{abstract}
Abstrak
Tujuan penelitia ini adalah untuk mengetahui pengaruh pemberian penguatan oleh guru Pendidikan Kewarganegaraan terhadap hasil belajar siswa kelas VII di SMP Negeri 4 Rasau Jaya Kabupaten Kubu Raya. Metodologi penelitian ini adalah metode deskriptif dengan bentuk penelitiannya adalah studi hubungan. Populasi dalam penelitian ini adalah siswa kelas VII di SMP Negeri 4 Rasau Jaya Kab. Kubu Raya berjumlah 35 Hasil penelitian ini menyatakan bahwa pemberian penguatan oleh guru Pendidikan Kewarganegaraan di kategorikan "Baik" dengan rata-rata sebesar 58,07\%, hal ini di dukung dengan pemberian penguatan verbal yang mencapai nilai $63 \%$, dan nonverbal yang mencapai nilai $55 \%$. Hasil belajar siswa dalam pembelajaran Pendidikan Kewarganegaraan kelas VII di SMP Negeri 4 Rasau Jaya Kabupaten Kubu Raya di kategorikan "baik" dengan rata-rata sebesar 72,91. Terdapat pengaruh pemberian penguatan oleh guru terhadap hasil belajar siswa dalam pembelajaran Pendidikan Kewarganegaraan kelas VII di SMP Negeri 4 Rasau Jaya Kabupaten Kubu Raya adalah sebesar 70,16\%.
\end{abstract}

Kata Kunci: Pemberian penguatan, hasil belajar, pendidikan kewarganegaraan

\begin{abstract}
The purpose of this research is to determine the effect of giving reinforcement by the Citizenship Education teacher on the learning outcomes of Grade VII students at SMP Negeri 4 Rasau Jaya, Kubu Raya Regency. This research methodology is descriptive method with the form of research is the study of relationships. The population in this study were students of class VII in SMP Negeri 4 Rasau Jaya Kab. Kubu Raya totals 35. The results of this study state that the provision of reinforcement by the Civics Education teacher is categorized as "Good" with an average of 58.07\%, this is supported by the provision of verbal reinforcement which reaches $63 \%$, and nonverbal which reaches $55 \%$. Student learning outcomes in class VII Citizenship Education learning in SMP Negeri 4 Rasau Jaya Kubu Raya Regency is categorized as "good" with an average of 72.91. There is an effect of giving reinforcement by teachers to student learning outcomes in learning Citizenship Education class VII in SMP Negeri 4 Rasau Jaya Kubu Raya Regency is $70.16 \%$.
\end{abstract}

Keywords: giving reinforcement, learning outcomes, citizenship education

\section{PENDAHULUAN}

Pendidikan merupakan usaha yang direncanakan yang dapat diartikan sebagai kegiatan untuk mewariskan budaya dari satu generasi kegenarsi lainnya. Pendidikan juga ditujukan untuk menyiapkan warga negara artinya pendidikan adalah sebagai suatu kegiatan yang terrencana untuk membekali peserta didik agar menjadi warga negara yang baik sesuai dengan tujuan pendidikan nasional yang tercantum dalam Undang-Undang No 20 Tahun 2003 tentang sistem pendidikan nasional pasal 3 mengatakan "Pendidikan nasional berfungsi untuk mengembangkan kemampuan dan membentuk watak serta peradaban bangsa bertujuan untuk berkembangnya potensi peserta didik agar menjadi manusia yang beriman dan bertakwa kepada Tuhan Yang Maha Esa, berakhlak mulia, sehat, berilmu, cakap, kreatif, mandiri dan menjadi warga Negara yang demokratis dan bertanggungjawab". 
Dengan demikian agar tujuan pendidikan yang ditentukan oleh Undang-Undang tentang sistem pendidikan nasional maka sangat diperlukan peran pendidik khusunya guru. Dalam hal ini tugas guru memberi bantuan dalam proses pembelajaran untuk menumbuhkan pertumbuhan dan perkembangan peserta didik melalui kegiatan belajar mengajar sangat diperlukan guna diarahkan kepada pencapaian perubahan tingkah laku, perkembangan ilmu pengetahuan serta meningkatkan kemampuannya dalam belajar, yaitu untuk mewujudkan suasana belajar, untuk itu guru hendaknya mampu melakukan perubahan dan penyesuaian-penyesuaian dengan siswa. Selain itu seorang guru dituntut untuk menguasai berbagai teknik, metode, strategi dan model pembelajaran.

Uzer Usman (2010:74) seorang guru dalam mengajar harus menguasai delapan keterampilan dasar dalam mengajar, diharapkan dengan menguasai keterampilan dalam mengajar diharapkan dapat meningkatkan kualitas pembelajaran. Adapun delapan keterampilan tersebut yaitu: "keterampilan bertanya, memberi penguatan, mengadakan variasi, menjelaskan, membuka dan menutup pelajaran, membimbing diskusi kelompok kecil,mengelola kelas dan, mengelola kelompok kecil dan perorangan.”

Dari beberapa keterampilan dasar mengajar yang harus dimiliki oleh seorang guru di atas, jelas bahwa melaksanakan tugas mengajar bagi seorang guru bukanlah perkara yang mudah. Guru dituntut untuk memiliki keterampilan mengajar yang kompleks, salah satunya ialah guru harus menguasai keterampilan dalam memberi penguatan. Keterampilan guru dalam memberikan penguatan yang tepat akan dapat meningkatkan perhatian siswa. Perhatian adalah sebuah kata-kata yang biasa bila didengar, tetapi perhatian akan sangat berharga bila kita sedang mengalami banyak masalah. Suatu perhatian akan sangat berarti bila diberikan dengan rasa penuh ikhlas dan tidak terpaksa.

Menurut Uzer Usman (2010:80) bahwa: "Penguatan (reinforcement) adalah segala bentuk respons, apakah bersifat verbal ataupun non verbal, yang merupakan bagian dari modifikasi tingkah laku guru terhadap tingkah laku siswa, yang bertujuan untuk memberikan informasi atau umpan balik (feedback) bagi si penerima (siswa) atas perbuatannya sebagai suatu tindakan dorongan atau koreksi, atau penguatan adalah respon terhadap suatu tingkah laku yang dapat meningkatkan berulangnya kembali tingkah laku tersebut." Penguatan harus diberikan guru dalam proses pembelajaran secara terus menerus sebagai upaya untuk mendorong tumbuhnya perilaku yang positif.

Sudah selayaknya dalam pembelajaran Pendidikan Kewarganegaraan dilakukan keterampilan memberi penguatan. Jika dalam pembelajaran siswa tidak aktif maka guru perlu memberikan penguatan untuk memotivasi belajar siswa dalam kegiatan belajar mengajar, maka 
dalam penelitian ini diupayakan pemberian penguatan oleh guru terhadap hasil belajar siswa. Selanjutnya dalam kegiatan belajar mengajar pemberian penguatan oleh guru kepada siswa di kaitkan dengan pemberian penguatan oleh guru terhadap hasil belajar siswa. Hasil belajar adalah perubahan tingkah laku subjek yang meliputi kemampuan kognitif, afektif, dan psikomotor dalam situasi tertentu berkat pengalamannya berulang-ulang.

Uraian di atas menjelaskan bahwa, keterampilan guru dalam memberikan penguatan yang tepat akan dapat meningkatkan perhatian siswa dan aktivitas belajar siswa. Menurut Aunurrahman (2014:130) menyatakan bahwa: "Ketepatan pemberian dan penggunaan penguatan harus mendapat perhatian guru. Bilamana penguatan dipergunakan pada situasi dan waktu yang tidak tepat, maka hal itu dapat kehilangan keefektifannya. Sebaliknya bilamana penguatan itu dipergunakan secara tepat, maka akan memberikan pengaruh yang positif terhadap aktivitas belajar peserta didik."

Dari beberapa pendapat para ahli tersebut maka dapat dirumuskan bahwa upaya guru dalam pemberikan penguatan kepada siswa di dalam kelas yang diberikan oleh guru untuk menciptakan suasana belajar yang kondusif dan mempertahankan minat, perhatian dan motivasi siswa untuk selalu ikut terlibat dan berperan serta dalam proses pembelajaran khususnya mata pelajaran PKn. Keterampilan memberikan penguatan verbal dan nonverbal yang di berikan oleh guru di dalam kelas menciptakan suasana belajar mengajar yang optimal. Pemberian penguatan oleh guru dapat memotivasi belajar siswa sehingga lebih giat lagi belajarnya dan hasilnya juga memuaskan, dan dapat mencapai prestasi yang lebih baik.

Berdasarkan hasil pra observasi yang dilakukan oleh peneliti di SMP Negeri 4 Rasau Jaya, khususnya kelas VII menunjukkan bahwa pemberian penguatan verbal dan nonverbal jarang diberikan oleh guru Pendidikan Kewarganegaraan hal ini dapat dilihat dari kurangnya kemampuan guru dalam memberikan anggukan, senyuman, atau acungan ibu jari. Jika hal ini dibiarkan akan mempengaruhi hasil belajar siswa khususnya dalam mata pelajaran Pendidikan Kewarganegaraan.

Berdasarkan pemikiran yang telah dipaparkan di atas, peneliti merasa tertarik untuk mengadakan penelitian dengan judul "Pengaruh Pemberian Penguatan Oleh Guru Terhadap Hasil Belajar Siswa Dalam Pembelajaran Pendidikan Kewarganegaraan Kelas VII di SMP Negeri 4 Rasau Jaya Kabupaten Kubu Raya”.

\section{METODE}

Metode yang digunakan adalah metode penelitian deskriptif bentuk penelitian yang cocok digunakan dalam penelitian ini adalah studi hubungan (interrelationship studies). Menurut Hadari Nawawi (Zuldafrial, 2012: 5) "penelitian diskriptif diartikan sebagai prosedur pemecahan masalah 
yang dislidiki dengan cara mengambarkan/melukiskan keadaan subjek atau objek penelitian (seseorang, lembaga, masyarakat dll) pada saat sekarang berdasarkan fakta-fakta yang tampak sebagaimana adanya".

Populasi dalam penelitian ini adalah 35 siswa kelas VII di SMP Negeri 4 Rasau Jaya Kabupaten Kubu Raya. karena jumlah populasi yang tersedia kurang dari 100 yaitu berjumlah 35 orang siswa. Berdasarkan pernyataan tersebut karena populasi dalam penelitian ini kurang dari 100 siswa, maka penelitian ini disebut penelitian populasi.

Teknik pengumpulan data yang digunakan dalam penelitian ini adalah teknik pengukuran, teknik komunikasi tidak langsung, teknik observasi langsung, dan teknik studi dokumenter. Alat pengumpul data yang digunakan dalam penelitian ini adalah tes, angket, panduan observasi dan dokumentasi.

\section{HASIL DAN PEMBAHASAN}

Setelah data penelitian yang diperoleh dari hasil pemeriksaan angket selanjutnya diolah berdasarkan teknik pengolahan yang telah ditetapkan sebelumnya. Berdasarkan hasil pengolahan data menunjukan bahwa:

\section{Pemberian Penguatan Oleh Guru Pendidikan Kewarganegaraan Kelas VII di SMP Negeri 4 Rasau Jaya Kabupaten Kubu Raya.}

Hasil olah data angket untuk variabel Pemberian Penguatan Oleh Guru Pendidikan Kewarganegaraan Kelas VII di SMP Negeri 4 Rasau Jaya Kabupaten Kubu Raya dapat dijabarkan dalam tabel berikut ini:

\section{Tabel 1}

Hasil Perhitungan Pemberian Penguatan Oleh Guru

\begin{tabular}{clrccc}
\hline \multicolumn{1}{c}{$\begin{array}{c}\text { Pemberian Penguatan } \\
\text { Oleh Guru PKn }\end{array}$} & $\begin{array}{c}\text { Skor } \\
\text { Aktual }\end{array}$ & $\begin{array}{c}\text { Skor } \\
\text { Ideal }\end{array}$ & \% & Kategori \\
\hline $\begin{array}{c}\text { Aspek } \\
\text { Variabel }\end{array}$ & \multicolumn{1}{c}{ Indikator } & $\mathbf{1 6 2 6}$ & $\mathbf{2 8 0 0}$ & $\mathbf{5 8}$ & Baik \\
\hline & $\begin{array}{l}\text { 1. Pujian } \\
\text { 2. Penghargaan }\end{array}$ & 177 & 280 & 63 & Baik \\
\cline { 2 - 6 } $\begin{array}{c}\text { 3. Persetujuan } \\
\text { Penguatan }\end{array}$ & $\begin{array}{l}\text { 4. Penguatan } \\
\text { Verupa kata- kata }\end{array}$ & 165 & 280 & 59 & Baik \\
\cline { 2 - 6 } & $\begin{array}{l}\text { Penguatan } \\
\text { gerak isyarat }\end{array}$ & 296 & 420 & 70 & Baik \\
\cline { 2 - 6 } & $\begin{array}{l}\text { Penguatan } \\
\text { pendekatan }\end{array}$ & 158 & 280 & 56 & Baik \\
\hline
\end{tabular}




\begin{tabular}{lllll}
\hline $\begin{array}{l}\text { Penguatan } \\
\text { dengan sentuhan }\end{array}$ & 115 & 280 & 41 & Cukup Baik
\end{tabular}

\begin{tabular}{llcccc} 
Penguatan & & & & \\
\cline { 2 - 5 } & $\begin{array}{l}\text { Penguatan } \\
\text { dengan kegiatan }\end{array}$ & 97 & 280 & 35 & Cukup Baik \\
\cline { 2 - 6 } & $\begin{array}{l}\text { Penguatan } \\
\text { berupa symbol atau } \\
\text { benda }\end{array}$ & 253 & 420 & 60 & Baik \\
& & $\mathbf{9 1 9}$ & $\mathbf{1 6 8 0}$ & $\mathbf{5 5}$ & Baik \\
\hline
\end{tabular}

Berdasarkan tabel 1 dapat diketahui hasil perhitungan untuk variabel bebas yaitu Pemberian Penguatan Oleh Guru adalah sebesar skor Aktual 1626 dari skor Ideal 2800 berarti mencapai nilai persentase 58\%. Dengan demikian pemberian penguatan oleh guru dapat di kategorikan "Baik" sesuai dengan tabel 1 tolok ukur kategori perhitungan presentase, ini berarti guru baik dalam memberikan penguatan dalam pembelajaran Pendidikan Kewarganegaraan kelas VII di SMP Negeri 4 Rasau Jaya Kabupaten Kubu Raya. Adapun penjelasan dari aspek variabel yaitu sebagai berikut:

1. Penguatan verbal dalam pemberian penguatan oleh guru terhadap hasil belajar siswa dalam pembelajaran Pendidikan Kewarganegaraan kelas VII di SMP Negeri 4 Rasau Jaya Kabupaten Kubu Raya mencapai nilai presentase 63\% dapat di kategorikan "Baik" sesuai tabel 1 tolok ukur kategori perhitungan presentase. Hal ini ditunjukan dengan:

a. Penguatan berupa pujian termasuk kategori "Baik" karena mencapai 63\%. Ini berarti guru baik dalam memberikan penguatan pujian dalam proses pembelajaran Pendidikan Kewarganegaraan.

b. Penguatan berupa penghargaan termasuk kategori "Baik" karena mencapai $68 \%$. Ini berarti guru baik dalam memberikan penguatan penghargaan dalam proses pembelajaran Pendidikan Kewarganegaraan.

c. Penguatan berupa persetujuan termasuk kategori "Baik" karena mencapai $62 \%$. Ini berarti guru baik dalam memberikan penguatan persetujuan dalam proses pembelajaran Pendidikan Kewarganegaraan.

d. Penguatan berupa kata-kata termasuk kategori "Baik" karena mencapai 59\%. Ini berarti guru baik dalam memberikan penguatan berupa kata-kata dalam proses pembelajaran Pendidikan Kewarganegaraan.

2. Penguatan nonverbal dalam pemberian penguatan oleh guru terhadap hasil belajar siswa dalam pembelajaran Pendidikan Kewarganegaraan kelas VII di SMP Negeri 4 Rasau Jaya Kabupaten 
Kubu Raya mencapai nilai presentase 55\% dapat di kategorikan "Baik" sesuai tabel 1 tolok ukur kategori perhitungan presentase. Hal ini ditunjukan dengan:

a. Penguatan gerak isyarat termasuk kategori "Baik" karena mencapai 70\%. Ini berarti guru baik dalam memberikan penguatan gerak isyarat dalam proses pembelajaran Pendidikan Kewarganegaraan.

b. Penguatan pendekatan termasuk kategori "Baik" karena mencapai 56\%. Ini berarti guru baik dalam memberikan penguatan pendekatan dalam proses pembelajaran Pendidikan Kewarganegaraan.

c. Penguatan dengan sentuhan termasuk kategori "Cukup Baik" karena mencapai $41 \%$. Ini berarti guru cukup baik dalam memberikan penguatan dengan sentuhan dalam proses pembelajaran Pendidikan Kewarganegaraan.

d. Penguatan dengan kegiatan termasuk kategori "Cukup Baik" karena mencapai 35\%. Ini berarti guru cukup baik dalam memberikan penguatan dengan kegiatan dalam proses pembelajaran Pendidikan Kewarganegaraan.

e. Penguatan berupa symbol atau benda termasuk kategori "Baik" karena mencapai $60 \%$. Ini berarti guru baik dalam memberikan penguatan berupa symbol atau benda dalam proses pembelajaran Pendidikan Kewarganegaraan.

Hasil olah data angket untuk variabel pemberian Penguatan Oleh Guru Pendidikan Kewarganegaraan Kelas VII di SMP Negeri 4 Rasau Jaya Kabupaten Kubu Raya dapat diketahui hasil perhitungan untuk variabel bebas yaitu Pemberian Penguatan Oleh Guru adalah sebesar skor Aktual 1626 dari skor Ideal 2800 berarti mencapai nilai persentase 58\%. Dengan demikian pemberian penguatan oleh guru dapat di kategorikan "Baik".

Menurut Uzer Usman (2010:80) menyatakan bahwa: "Penguatan (reinforcement) adalah segala bentuk respon, apakah bersifat verbal maupun non verbal, yang merupakan bagian dari modifikasi tingkah laku guru terhadap tingkah laku siswa, yang bertujuan untuk memberikan informasi atau umpan balik (feedback) bagi si penerima (siswa) atas perbuatannya sebagai suatu tindakan dorongan atau koreksi, atau penguatan adalah respon terhadap suatu tingkah laku yang dapat meningkatkan berulangnya kembali tingkah laku tersebut."

Berdasarkan pendapat di atas dapat disimpulkan pemberian penguatan guru adalah pemberian segala respon yang dilakukan oleh guru dalam kegiatan belajar mengajar, dimana respon-respon tersebut adalah mampu membangkitkan semangat belajar siswa dalam mengikuti kegiatan proses belajar mengajar. Adapun tindakan atau perbuatan yang dilakukan oleh guru dalam pemberian penguatan ini dapat bersifat verbal atau non verbal. Hal ini sejalan dengan pendapat 
yang dikemukakan Aunurrahman (2014:129) yang menyatakan bahwa ada beberapa penguatan yang dapat dilakukan oleh guru seperti penguatan verbal, penguatan gestural, penguatan dengan mendekati, penguatan dengan sentuhan, penguatan dengan cara memberikan kegiatan yang menyenangkan, dan penguatan berupa tanda atau benda.

Berdasarkan berdasarkan temuan penelitian dan pendapat para ahli dapat disimpulkan bahwa penguatan sangat penting untuk diberikan oleh guru untuk membangkitkan semangat dan motivasi siswa dalam mengikuti pelajaran. Guru dapat memberikan penguatan berupa verbal (dengan katakata) atau non verbal (sentuhan atau gestur badan).

\section{Hasil Belajar Siswa Dalam Pembelajaran Pendidikan Kewarganegaraan Kelas VII di SMP Negeri 4 Rasau Jaya Kabupaten Kubu Raya.}

Hasil belajar siswa diketahui melalui nilai ulangan harian yang disertakan kepada 35 orang siswa kelas VII di SMP Negeri 4 Rasau Jaya Kabupaten Kubu Raya. Hasil nilai ulangan harian siswa untuk variabel Hasil Belajar Siswa kelas VII di SMP Negeri 4 Rasau Jaya Kabupaten Kubu Raya. Hasil nilai ulangan harian siswa untuk variabel Hasil Belajar Siswa kelas VII di SMP Negeri 4 Rasau Jaya Kabupaten Kubu Raya dapat dijabarkan.

\section{Tabel 2}

\section{Hasil Perhitungan Hasil Belajar Siswa}

\begin{tabular}{llcc}
\hline No & \multicolumn{1}{c}{ Nama } & Nilai & Kategori \\
\hline 1 & Abdul Kadir & 75 & Baik \\
\hline 2 & Ade Saputra & 70 & Baik \\
\hline 3 & Annisa Malahayati & 70 & Baik \\
\hline 4 & Arfan Fathurrahman & 75 & Baik \\
\hline 5 & Ari & 72 & Baik \\
\hline 6 & Arjuna & 70 & Baik \\
\hline 7 & Defi Wulandari & 80 & Sangat Baik \\
\hline 8 & Donny Fadilla & 73 & Baik \\
\hline 9 & Eka Novianti & 80 & Sangat Baik \\
\hline 10 & Elva Elvani & 70 & Baik \\
\hline 11 & Fadhil & 72 & Baik \\
\hline 12 & Febriyanto & 70 & Baik \\
\hline 13 & Ikhsan Septianto & 74 & Baik \\
\hline 14 & Japri & 70 & Baik \\
\hline 15 & Mardiono & 70 & Baik \\
\hline 16 & Muhammad Ikwanul Abidin & 75 & Baik \\
\hline 17 & Muhammad Reza & 75 & Baik \\
\hline 18 & Nita & 70 & Baik \\
\hline 19 & Novia & 74 & Baik \\
\hline 20 & Pornomo & 74 & Baik \\
\hline 21 & Rengga Purnama Putra & 72 & Baik \\
\hline 22 & Rian Yulianto & 70 & . \\
\hline & & & \\
\hline
\end{tabular}




\begin{tabular}{llcc}
\hline 23 & Richky Setiawan & 73 & Baik \\
\hline 24 & Rudi Hariyanto & 72 & Baik \\
\hline 25 & Sarjima & 74 & Baik \\
\hline 26 & Siti Nurhasannah & 70 & Baik \\
\hline 27 & Siyani & 70 & Baik \\
\hline 28 & Sri Wahyu Ningsih & 75 & Baik \\
\hline 29 & Sulastri Ningsih & 78 & Baik \\
\hline 30 & Susendi Pratama & 73 & Baik \\
\hline 31 & Suwardi & 75 & Baik \\
\hline 32 & Vaices Merpina & 70 & Baik \\
\hline 33 & Wahyu Kurniawan & 73 & Baik \\
\hline 34 & Yogi & 72 & Baik \\
\hline 35 & Yuni Gusmita & 76 & Baik \\
\hline & $\sum \mathbf{Y}$ & $\mathbf{2 5 5 2 : 3 5}$ & $\mathbf{7 2 , 9 1}$ \\
\hline
\end{tabular}

Selanjutnya untuk mengetahui nilai rata-rata (mean) dari hasil belajar siswa kelas VII di SMP Negeri 4 Rasau Jaya Kabupaten Kubu Raya dilakukan dengan rumus mean menurut Sugiyono (2010:49) sebagai berikut:

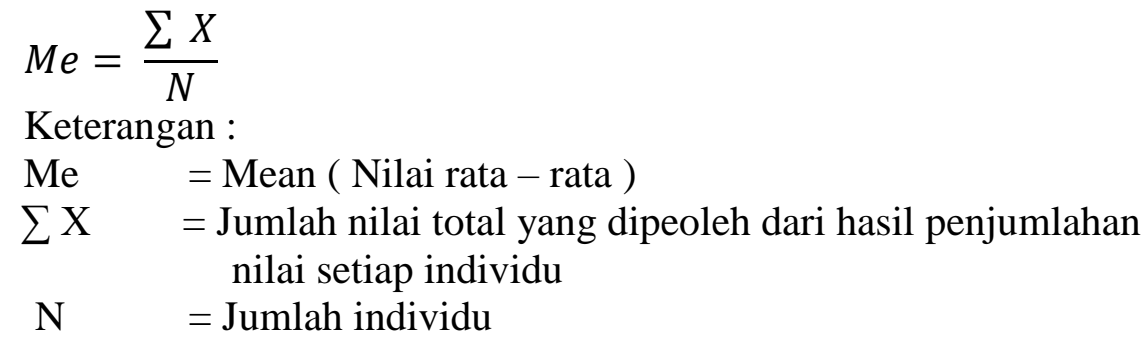

Berdasarkan rumus di atas, maka nilai rata - rata untuk hasil belajar siswa kelas VII di SMP Negeri 4 Rasau Jaya Kabupaten Kubu Raya adalah:

$$
\begin{aligned}
M & =\frac{\sum X}{N} \\
& =\frac{2552}{35} \\
& =72,91
\end{aligned}
$$

Dengan demikian mean ( nilai rata-rata ) hasil belajar siswa kelas VII di SMP Negeri 4 Rasau Jaya Kabupaten Kubu Raya adalah sebesar 72,91 dengan demikian dikategorikan "BAIK".

Hasil belajar adalah dampak dari pengalaman yang berulang-ulang sehingga terjadi perubahan tingkah laku subjek yang meliputi kemampuan kognitif, afektif, dan psikomotor dalam situasi tertentu. Hasil belajar siswa merupakan tingkat keberhasilan siswa dalam mencapai materi pelajaran di sekolah dalam bentuk skor yang diperoleh dari tes mengenai sejumlah materi Adapun yang dimaksud hasil belajar siswa dalam penelitian ini adalah tingkat keberhasilan kognitif siswa dalam pelajaran Pendidikan Kewarganegaraan. Pernyataan di atas sejalan dengan pendapat yang Menurut Bloom (Uzer Usman, 2010) yang mengklasifikasikan hasil belajar menjadi tiga ranah, 
yaitu kognitif, afektif dan psikomotorik. Seorang guru harus menumbuhkan ketiga ranah ini secara keseluruhan.

Besarnya Pengaruh Pemberian Penguatan Oleh Guru Terhadap Hasil Belajar Siswa Dalam Pembelajaran Pendidikan Kewarganegaraan Kelas VII di SMP Negeri 4 Rasau Jaya Kabupaten Kubu Raya.

Berdasarkan hasil angket yang diberikan peneliti kepada responden maka dapat diketahui bahwa pemberian penguatan oleh guru berpengaruh terhadap hasil belajar siswa, hal ini dapat dilihat pada tabel 3

Tabel 3

Hasil Perhitungan Pemberian Penguatan

\begin{tabular}{|c|c|c|c|c|c|c|}
\hline No & Nama & $(\mathbf{X})$ & $(\mathbf{Y})$ & $\mathbf{X}^{2}$ & $\mathbf{Y}^{2}$ & $\mathbf{X Y}$ \\
\hline 1 & Abdul Kadir & 55 & 75 & 3025 & 5625 & 4125 \\
\hline 2 & Ade Saputra & 37 & 70 & 1369 & 4900 & 2590 \\
\hline 3 & Annisa Malahayati & 37 & 70 & 1369 & 4900 & 2590 \\
\hline 4 & Arfan Fathurrahman & 47 & 75 & 2209 & 5625 & 3525 \\
\hline 5 & Ari & 45 & 72 & 2025 & 5184 & 3240 \\
\hline 6 & Arjuna & 51 & 70 & 2601 & 4900 & 3570 \\
\hline 7 & Defi Wulandari & 43 & 80 & 1849 & 6400 & 3440 \\
\hline 8 & Donny Fadilla & 48 & 73 & 2304 & 5329 & 3504 \\
\hline 9 & Eka Novianti & 36 & 80 & 1296 & 6400 & 2880 \\
\hline 10 & Elva Elvani & 35 & 70 & 1225 & 4900 & 2450 \\
\hline 11 & Fadhil & 41 & 72 & 1681 & 5184 & 2952 \\
\hline 12 & Febriyanto & 58 & 70 & 3364 & 4900 & 4060 \\
\hline 13 & Ikhsan Septianto & 54 & 74 & 2916 & 5476 & 3996 \\
\hline 14 & Japri & 45 & 70 & 2025 & 4900 & 3150 \\
\hline 15 & Mardiono & 44 & 70 & 1936 & 4900 & 3080 \\
\hline 16 & Muhammad Ikwanul Abidin & 48 & 75 & 2304 & 5625 & 3600 \\
\hline 17 & Muhammad Reza & 49 & 75 & 2401 & 5625 & 3675 \\
\hline 18 & Nita & 45 & 70 & 2025 & 4900 & 3150 \\
\hline 19 & Novia & 38 & 74 & 1444 & 5476 & 2812 \\
\hline 20 & Pornomo & 46 & 74 & 2116 & 5476 & 3404 \\
\hline 21 & Rengga Purnama Putra & 43 & 72 & 1849 & 5184 & 3096 \\
\hline 22 & Rian Yulianto & 73 & 70 & 5329 & 4900 & 5110 \\
\hline
\end{tabular}




\begin{tabular}{llccccc}
\hline 23 & Richky Setiawan & 48 & 73 & 2304 & 5329 & 3504 \\
\hline 24 & Rudi Hariyanto & 50 & 72 & 2500 & 5184 & 3600 \\
\hline 25 & Sarjima & 45 & 74 & 2025 & 5476 & 3330 \\
\hline 26 & Siti Nurhasannah & 52 & 70 & 2704 & 4900 & 3640 \\
\hline 27 & Siyani & 41 & 70 & 1681 & 4900 & 2870 \\
\hline 28 & Sri Wahyu Ningsih & 43 & 75 & 1849 & 5625 & 3225 \\
\hline 29 & Sulastri Ningsih & 38 & 78 & 1444 & 6084 & 2964 \\
\hline 30 & Susendi Pratama & 47 & 73 & 2209 & 5329 & 3431 \\
\hline 31 & Suwardi & 51 & 75 & 2601 & 5625 & 3825 \\
\hline 32 & Vaices Merpina & 67 & 70 & 4489 & 4900 & 4690 \\
\hline 33 & Wahyu Kurniawan & 45 & 73 & 2025 & 5329 & 3285 \\
\hline 34 & Yogi & 45 & 72 & 2025 & 5184 & 3240 \\
\hline 35 & Yuni Gusmita & 36 & 76 & 1296 & 5776 & 2736 \\
\hline & $\quad \mathbf{N}=\mathbf{3 5}$ & $\mathbf{1 6 2 6}$ & $\mathbf{2 5 5 2}$ & $\mathbf{7 7 8 1 4}$ & $\mathbf{1 8 6 3 5 0}$ & $\mathbf{1 1 8 3 3 9}$ \\
\hline
\end{tabular}

Keterangan :

$$
\begin{aligned}
& \mathrm{X}: 1626 \mathrm{X}^{2:} 77814 \quad \mathrm{XY}: 118339 \\
& \mathrm{Y}: 2552 \begin{array}{c}
\mathrm{Y}^{2}: 186350 \\
\mathrm{n}: 35
\end{array} \\
& r=\frac{n \sum x y-\left(\sum x\right)\left(\sum y\right)}{\sqrt{\left\{\left(n \sum x^{2}\right)-\left(\sum x\right)^{2}\right\}\left\{\left(n \sum y^{2}\right)-\left(\sum y\right)^{2}\right\}}} \\
&=\frac{35.118339-(1626)(2552)}{\sqrt{\left\{(35.77814)-(1626)^{2}\right\}\left\{(35.186350)-(2552)^{2}\right\}}} \\
&=\frac{4141865-4149552}{\sqrt{\{(2723490)-(2643876)\}(6522250)-(6512704)\}}} \\
&=\frac{7687}{\sqrt{(79614)(9546)}} \\
&=\frac{7687}{\sqrt{75995244}} \\
&=\frac{7687}{27568,01} \\
&=0.8376
\end{aligned}
$$

Hasil perhitungan di atas diperoleh untuk taraf kesalahan 5\% dengan $\mathrm{n}=35$ diperoleh nilai $r_{\text {tabel }}=0.334$ dan nilai $r_{\text {hitung }} 0.8376$. Maka 0,8376 $>0.334$ berarti $r_{\text {hitung }}$ lebih besar dari $r_{\text {tabel }}$. Maka dapat disimpulkan terdapat pengaruh yang positif dan signifikan sebesar 0,8376 antara pemberian penguatan oleh guru dan hasil belajar siswa.

Koefisien determinasinya $\mathrm{r}^{2}=0,8376^{2}=0,7016$. Berdasarkan perhitungan tersebut besarnya pengaruh pemberian penguatan oleh guru terhadap hasil belajar siswa dalam pembelajaran 
Pendidikan Kewarganegaraan kelas VII di SMP Negeri 4 Rasau Jaya Kabupaten Kubu Raya, secara umum adalah sebesar 70,16\%.

Dengan hal ini pengaruh pemberian penguatan oleh guru terhadap hasil belajar siswa dalam pembelajaran Pendidikan Kewarganegaraan beriringan untuk mencapai suatu tujuan pembelajaran yang efektif dan efisien yang dapat membantu mengembangkan kemampuan guru dalam mendidik siswa serta meningkatkan hasil belajar siswa. Terlihat berdasarkan korelasi product moment, bahwa besarnya pengaruh pemberian penguatan oleh guru terhadap hasil belajar siswa dalam pembelajaran Pendidikan Kewarganegaraan kelas VII di SMP Negeri 4 Rasau Jaya Kabupaten Kubu Raya di dapat hasil sebesar $70 \%$.

Hasil penelitian ini sejalan dengan penlitian yang dilukakan oleh Vandriyanti, H, dkk (2013) dimana hasil penelitian menunjukkan ada pengaruh yang signifikan antara pemberian penguatan oleh guru terhadap hasil belajar PKn siswa kelas VIII SMP Negeri 1 Jati Agung. Hal ini berarti semakin kuat pemberian penguatan oleh guru semakin tinggi tingkat hasil belajar PKn. Selanjutnya penelitian relevan juga dilakukan oleh Azriyusa, A (2014) hasil penelitiannya menunjukkan ada pengaruh pemberian penguatan oleh guru terhadap hasil belajar matematika siswa kelas VII SMP Negeri 1 Kamal pada materi bilangan bulat dan keterampilan guru mengajar dalam memberikan penguatan di kelas VII SMP Negeri 1 Kamal pada materi bilangan bulat sangat baik dengan rata-rata 81,5 .

\section{SIMPULAN}

Berdasarkan hasil pengolahan data dan analisis data yang telah disajikan, maka secara umum dapat ditarik kesimpulan terdapat pengaruh pemberian penguatan oleh guru terhadap hasil belajar siswa dalam pembelajaran Pendidikan Kewarganegaraan kelas VII di SMP Negeri 4 Rasau Jaya Kabupaten Kubu Raya yaitu sebesar 70,16\%. Pemberian penguatan oleh guru Pendidikan Kewarganegaraan kelas VII di SMP Negeri 4 Rasau Jaya Kabupaten Kubu Raya di kategorikan "Baik" dengan rata-rata hasil angket yang di peroleh adalah sebesar 58,07\%, hal ini di dukung dengan pemberian penguatan verbal yang mencapai nilai 63\%, dan nonverbal yang mencapai nilai $55 \%$ oleh guru Pendidikan Kewarganegaraan. Hasil belajar siswa dalam pembelajaran Pendidikan Kewarganegaraan kelas VII di SMP Negeri 4 Rasau Jaya Kabupaten Kubu Raya di kategorikan "baik" dengan rata-rata (mean) sebesar 72,91 \%. Hal ini di pengaruhi adanya pemberian penguatan oleh guru Pendidikan Kewarganegaraan. Terdapat pengaruh pemberian penguatan oleh guru terhadap hasil belajar siswa dalam pembelajaran Pendidikan Kewarganegaraan kelas VII di SMP Negeri 4 Rasau Jaya Kabupaten Kubu Raya adalah sebesar 70,16\%. 


\section{DAFTAR PUSTAKA}

Aunurrahman. (2014). Belajar dan Pembelajaran. Bandung: Penerbit ALFABETA.

Azriyusa, A (2014). Pengaruh Pemberian Penguatan Terhadap Hasil Belajar Matematika Siswa Kelas VII SMP Negeri 1 Kamal Pada Materi Bilangan Bulat. Jurnal MATHEdunesa: Volume 3 No. (1).

Sugiyono. (2010). Statistika untuk Penelitian. Bandung: Alfabeta.

Undang-Undang Republik Indonesia. No. 20 Tahun 2003. Tentang Sistem Pendidikan Nasional. Jakarta: Pustaka Widyatama.

Usman, M.U. (2010). Menjadi Guru Profesional. Bandung: PT. Remaja Rosdakarya.

Vandriyanti, H, dkk (2013). Pengaruh Pemberian Penguatan oleh Guru Terhadap Hasil Belajar PKn Siswa. Jurnal Kultur Demokrasi, Volume 1 (6): 10.

Zuldafrial. (2012). Penelitian Kuantitatif. Yogyakarta: Media Perkasa Yogyakarta. 